UDC: $347.1 / 7(4) .001 .11$

V.Zarosylo ${ }^{1}$, Cand. Sc. (Jurid.), orcid.org/0000-0003-2452-264X,

Yu. Korostashyvets ${ }^{1}$, Cand. Sc. (Jurid.), orcid.org/0000-0002-9861-091X,

L. Maksymova ${ }^{2}$, Cand. Sc. (Jurid.), Assoc. Prof., orcid.org/0000-0001-7660-6779,

S. Nechyporuk ${ }^{3}$, Cand. Sc. (Jurid.), orcid.org/0000-0002-1972-2877
DOI: $10.29202 /$ nvngu/2018/19

1 - Kyiv State College of Tourism and Hotel Management, Kyiv, Ukraine, e-mail: juliakutep@gmail.com

2 - Kyiv University of Tourism, Economics and Law, Kyiv, Ukraine, e-mail: laramaximova@gmail.com

3 - National School of Judges of Ukraine, Kyiv, Ukraine, e-mail: mfkoorg@gmail.com

\title{
FEATURES OF THE LEGAL PROTECTION OF PROPERTY RIGHTS IN UKRAINE AND THE EUROPEAN UNION
}

Purpose. To develop strategy of development of Institution of right of ownership which will act as an important part of the national security strategy. To consider legislative ways of increasing the investment attractiveness and economic potential of Ukrainian enterprises, the level of social protection of the population. Based on the experience of property rights protection in the European Union member States, to prove that the basis for the legal protection of property rights should be economic feasibility rather than the political situation of the Executive branch and the legislature.

Methodology. The authors used the method of comparative legal analysis, which allowed comparing the features of legal protection of property rights in Ukraine and the countries of the European Union and coming to certain conclusions. The historical and legal method allowed the authors to establish the patterns and trends of property rights protection in general and in separate elements. The logical-legal method of scientific knowledge allowed the authors to draw conclusions that are necessary to underpin the social significance of the Institution of property rights in Ukraine.

Findings. The authors found three causes of instability of the Institution of property rights in Ukraine:

1. The Institution of the right of ownership is formed and evolves exclusively within the borders of legal science, while in the states of the European Union, property rights are seen primarily through the lens of economic theories.

2. Relatively short history of development of legal protection of property rights and the impact of post-Communist ideology.

3. Lack of formation of traditions of respect for private property and the right to protection of property in the educational programs of secondary and higher educational establishments.

The identified causes do not only fail to contribute to the development of the institution of property rights and its legal protection, but also undermine the economic and national security of Ukraine.

Originality. The authors found that the legal protection of property rights is an important characteristic of the economic security of Ukraine. The authors proposed the strategy to develop the Institution of right of ownership, which has an important influence on the security strategy of Ukraine. The development strategy of the Institution of law of ownership includes the following main provisions: legislation that provides legal protection of property rights in Ukraine, should proceed from economic and social theories; basics of legal protection of property rights should be included in educational curricula in secondary educational establishments so that students know the constitutional norms which protect them from property and moral damage; it is necessary that in the models of the educational landscape, the Institution of the right of ownership was considered as one of the foundations of economic and, consequently, national security strategy of Ukraine; the Ukrainian national idea should include not only a national and cultural component, but also an economic one. In the modern realities, the economic power of the state is the defining characteristic of its geopolitical ambitions.

Practical value. The results obtained during the research can be used: a) in the research field on issues of protecting ownership rights; $b$ ) in the sphere of law-making to improve laws and regulations governing property rights in Ukraine; c) in judicial practice for uniform application of the provisions of the civil law when considering disputes connected with legal protection of property rights in the courts of General jurisdiction and economic courts.

Keywords: institution of property right, economic security, economic analysis of law, economic theory of property right

Introduction. One of the main issues of economic security of any state is the issue of legal protection of property rights, which guarantees sustainable economic development of the state. If in most states of the European Union the Institution of law of the ownership has occupied and occupies a central place in the legislative, executive and judicial powers throughout the history of

CC Zarosylo V., Korostashyvets Yu., Maksymova L., Nechyporuk S., 2018 the state, in Ukraine, the Institution of rights of ownership has been formed for only a few decades. We do not take into account the legal heritage of the USSR, which from the authors' point of view, on the contrary, prevented the establishment of the institution of property rights and its social significance during the first twenty years of independence of Ukraine. The influence of organizational and ideological heritage of the Soviet Union, on the one hand, the lack of authority and sup- 
port in society of the importance of the Institution of ownership rights, on the other hand, and, on a separate note, inconsistence and opportunism of the state policy in the field of legal protection of property rights in Ukraine - all have allowed illegal takeovers of enterprises, created an unfavorable investment climate, undermined the economic security of the country, and contributed to corruption up to the present time. This issue is considered in the research by Oleg Bazaluk [1], Zaid Rahmani and Vadym Tytarenko [2], and others.

In the article the authors will propose a strategy of development of the Institution of right of ownership, which is essentially one of the main characteristics of the national security strategy. The proposed strategy aims to increase the investment attractiveness and economic potential of Ukrainian enterprises, improve the level of social protection of the population. Based on the experience of property rights protection in the European Union, the authors prove that the basis for the legal protection of property rights should be economic feasibility rather than the political situation of the executive branch and the legislature.

Analysis of the recent research. Article 13 of the Constitution of Ukraine proclaims: "The State protects the rights of all subjects of ownership and management, social orientation of the economy. All subjects of property rights are equal before the law". However, the analysis of the current judicial practice in Ukraine proves the absence of a common position of the judiciary in the resolution of disputes related to violation of property rights. Courts of General jurisdiction and economic courts ambiguously apply the current statutory regulations when considering disputes connected with legal protection of property rights in Ukraine. Uncertainty and controversial decisions of the judiciary on issues of property rights protection in Ukraine lead to the violation of the constitutional rights of owners and, accordingly, to undermining of the economic foundations of the state and its national security. The research of A. Hnativ [3], E. Haritonov [4], and others is devoted to this issue.

Presentation of the main research. The ownership in Ukraine is protected by the rules of civil, criminal, administrative, constitutional and other law. In essence, the phrase "legal protection of property rights" implies a set of legal ways to protect property that was used by the court, state authorities or by the owner. For the state, legal protection of property rights is of great importance because in the modern realities, the property in its various forms is the basis for economic development. Mainly, property rights protection is provided by the civil law specifically designed for this purpose. A feature of the legal protection of property rights, unlike other types of legal protection is that it aims to restore the violated rights, pre-property status of the person whose rights are breached.

At first glance, the legal basis for protection of ownership in Ukraine is more than enough. This is Article 13 of the Constitution of Ukraine; Article 16 of the civil code of Ukraine; article 386 of the civil code of Ukraine; on a number of special legislative acts [5]. For example, article 386 of the Civil Code, developing the provisions of Article 13 of the Constitution of Ukraine states that the state shall equally protect the rights of all subjects of ownership.

Civil-law ways of protection of property rights in Ukraine are quite heterogeneous in their content and application. Some of them are aimed at the protection of property rights directly, others indirectly. However, the legislation does not provide for a specific classification of means of protection of property rights. In the literature, the most common technique is the division of legal remedies of the right of ownership into material and binding legal relationship. However, the unity concerning the occurrence of specific protection does not exist. In practice this yields to a dual interpretation of the mentioned articles and statutes, lumping together close, but not identical concepts, methods and forms of protection of civil rights. For example, Article 19 of the Civil Code of Ukraine is called "self-defense of civil rights". Based on the title of the article we are talking only about civil rights and it does not affect the interests of the person. Thus, in the article it is noted that selfdefense must "not be contrary to the moral foundations of society" that is the inner manifestation of interest of the person. The Civil Code of Ukraine does not contain a clear list of measures of self-defense in both the real and binding legal relationship that initially causes any controversial decision. The judiciary at its discretion can enlarge and narrow the list of possible violations.

The validity of a controversial interpretation of fundamental laws and regulations governing property rights in Ukraine produces the loss of the owners of the businesses, unwillingness of investors to take risks and to invest in fixed assets of enterprises and, consequently, the overall instability in the economy of Ukraine. To the lack of a market for land on which enterprises are located, the possibility of raider captures of the enterprises themselves is added. Ultimately, this yields to the fact that the bulk of investment in Ukraine comes for a short period and does not cause the growth of the capital stock.

Analysis of the legal protection of property rights in the member states of the European Union allows us to define three main causes of instability of the Institution of right of ownership in Ukraine.

The first reason. In Ukraine, the Institution of the right of ownership has developed and evolves exclusively within the boundaries of the legal science. Defining legislative acts, establishing and regulating the rights of ownership are created in narrow, specialized discourse of law, of jurisprudence. In the European Union, property rights are seen primarily through the lens of economic theories and social theories. This is interdisciplinary research in which law plays an important but not decisive role.

Analysis of English-language literature on the issue of property rights reveals the following features:

1. The greatest number of studies which lay down the ideas that form the basis of the modern European Institution of property rights, falls on the late 60-ies and early 70 -ies of the $20^{\text {th }}$ century. For example, in 1974 in the book "Classic Papers in Natural Resource Econom- 
ics" an article "Toward a theory of property rights" by Harold Demsetz was published. In 1972 there was published an article "Property Rights and Economic Theory: A Survey of Recent Literature" by Eirik G. Furubotn and Svetozar Pejovich followed by an article "The Property Right Paradigm" by Armen A. Alchian and Harold Demsetz in 1973, and others.

2. Western traditions suggest a determining influence of economic theories on tightening the legal protection of property rights.

3. In 1974, Richard Posner introduced economic analysis of law for discussion. Posner argued that the law should be determined by economic expediency, i.e. to ensure the effectiveness of the state's economy. In 2014, the ninth edition of the book "Economic Analysis of Law" by Richard Posner was published [6].

Thus, the basis for legal protection of property rights in the European Union states is the economic theory of property rights which is directly related to social theories. While in Ukraine peculiarities of legal protection of property rights are defined by the legislative branch and policy, in the European Union general provisions of the law are regarded from the point of view of their effectiveness and benefit to the economy of the state and, accordingly, social protection of the population. In the European Union, the economy and its development define features of legal protection of property rights.

The second reason. The authors believe that the second reason for the instability of the legal Institution of ownership in Ukraine is the relatively short history of development of legal protection of property rights compared to the countries of the European Union. Analyzing works in this area, the authors paid attention to the key role of ideological approaches prevailing in Ukraine. For example, studies by Iryna Fatkhutdinova [7], Oleksandr Cheremisin and Mykola Herasymenko [8], and others reveal the dominant influence of ideology on the development of political, economic, social and cultural relations in Ukraine. Rejection of private ownership in the USSR, led to the fact that in the post-Soviet space, including in Ukraine, up to date legal protection of property rights has been perceived from the perspective of double standards. On the one hand, it is protected by laws and legislative acts; on the other hand, it is not considered as a basis of economic development of the state and the welfare of the people. Unlike in the states of the European Union, the legal protection of property rights is not considered in strategies for economic and national security of Ukraine [9].

A completely different history of the Institution of legal ownership can be observed in the European Union, not burdened with the Communist ideology. The modern concept of legal protection of property rights was formulated in the late $19^{\text {th }}$ century. They were changed only under the influence of the two world wars. The basic ideas of modern Western understanding of the Institution of property rights were formulated in the universal Declaration of Human Rights on 10 December 1948. In 1950, on the basis of the universal Declaration the Convention for the Protection of Human Rights and Fundamental freedoms was developed (European Con- vention on Human Rights), which entered into force on 3 September 1953. The Convention enshrined the fundamental Western ideas of the Institution of property rights and created effective mechanisms for protection of the rights declared in the European Court of Human Rights. Analysis of national security strategies of European states shows the key importance of the legal protection of property rights, which ensures investment attractiveness of states, economic growth and social protection of the population [10].

The third reason. The third cause of instability of the legal Institution of ownership in Ukraine is the lack of appropriate topics in educational programs of secondary and higher educational establishments. Education, as a technology of formation of steady stereotypes of the population is considered in the works of Vasyl Fatkhutdinov [9], Oleg Bazaluk [11, 12], and others. In the educational system of Ukraine there is no tradition of building respect for private property and the protective right to property; educational programs have not been created that consider the possibilities of legal protection of property rights; there is a lack of continuity and culture of the formation of the institution of property rights.

In the European Union, respect for the institution of private property is formed from childhood. It is transmitted in art, literature, mass media, social networks and so forth. This is an indispensable part of the Western culture, which ensures not only the legal protection of property rights, but also the support of society and all institutions of state power. An entire philosophical tradition is passed on from generation to generation, and guarantees sustainable respect for the right of ownership and confidence in the legal protection of property rights.

Up to the present time, the foregoing causes have posed a threat to the Institution of ownership in Ukraine. The lack of professionalism of the legislature, and corruption, yields to the fact that the state of Ukraine, instead of acting as a guarantor of property rights and legal protection for the ownership rights to its territory, violates the right of protection of property rights itself and creates a conflict between the subjects of property rights. Of many examples, we cite the following. Part 3 of Article 8 of the law of Ukraine "On organization and holding of Final Part of the 2012 European Football Championship in Ukraine" as amended by the Law of 5 June 2009 , regarding the decision to purchase private ownership by a legal object involves only fixing a time limit within which a deal for buying such an object must be closed. And the legislator does not say anything about whether the owner of the land will be aware of such a decision. In the Law the legislator does not prescribe the obligation of the authority to inform the land owners in the case of a decision on expropriation of real estate in profit of the state. Ultimately, this uncertainty in the Law, and essentially, manifested violation of the ownership rights, has led to numerous legal battles. In this example, the state apart from violating property rights of citizens also created a conflict in the legal protection of property rights. The judicial authorities were forced to make decisions based on their own your discretion, as, 
on the one hand, Article 13 of the Constitution of Ukraine obliges the state to be on guard of property rights, on the other hand, the legislature adopted a Law that violates property rights. Let us note that the litigations associated with the alienation of property as amended by the Law dated 5 June 2009 have continued to the present.

The inconsistency of defining laws and regulations in Ukraine opens a broad range of possibilities for the courts which do not relate to the competencies of the judiciary. Consider the following example. According to the order of State Registration of Immovable Property Rights and Encumbrances (http://zakon3.rada.gov.ua/ laws/show/868-2013-\%D0\%BF) one of the documents confirming the origin, transfer and termination of rights to immovable property is the court decision that has entered into legal force. However, the Order of Acceptance of Completed Construction Object into Operation (http://zakon5.rada.gov.ua/laws/show/461-2011-\%D0 $\% \mathrm{BF}$ ) provides that after recognition of the right of ownership to the construction site (including the illegally constructed real property), it should be taken into operation in the manner prescribed by law. In practice, the inconsistency of legislative acts has led to the fact that in Ukraine the number of self-constructed real property that does not meet the state architectural and construction standards has increased dramatically. The courts accepted the extrinsic functions and based on their solutions have commissioned self-built properties. Essentially, the courts took over the functions of the State Architectural and Construction Inspection, while having no appropriate qualifications.

The authors have to state that in Ukraine there is no strategy of development of the Institution of ownership right; legal science develops in isolation from economic and social sciences; the laws and other normative-legal acts in Ukraine are not conditioned by economic expediency, but by the political situation of the Executive branch and the legislature. This situation does not only fail to contribute to the development of the Institution of ownership rights and legal protection of property rights, but also undermines the foundations of economic and, consequently, national security of Ukraine.

Based on the study of the experience of European Union countries, which have a long history of development of the Institution of ownership right, the authors propose the following strategy of development of the Institution of ownership right in Ukraine.

Firstly, the basis of civil-law methods for protection of property rights in Ukraine should include the economic theory of property rights. Proposed in 1974 by Richard Posner, the economic theory of the right of ownership plays a key role in lawmaking of the states of Western Europe. It is a mistake to consider the development of property rights in the closed discourse of juridical sciences. It is an economic and social discourse in which legal sciences play a systematizing and legislative role rather than a determining one.

Secondly, the basic provisions of legal protection of property rights should be involved in educational programs of secondary schools. The Institution of prop- erty rights and the possibility of legal protection of property rights should be formed in younger generations as a way of life [13]. For these purposes it is necessary to use the experience of Poland and other European countries which have worked their way from decommunization [14]. At least at high school, students should know that the norm of Part 2 of Article 386 of the Civil Code guarantees the owner the opportunity to require not only the elimination of violations of their property rights, which have already taken place, but to go to court to protect their rights, which can really be breached in the future, i.e. to apply such a method to protect their violated rights, as a warning or possible termination of infringement of the owner in the future. Part 3 of Article 386 of the Civil Code establishes the right of the owner to compensation for property or moral damage in case of violation of their rights. It is especially necessary to know that according to Article 32 if the damage was caused by collecting, storing, using and disseminating false information about them and their family members, the owner has the right to compensation for property and moral damage. Constitutional provisions protect the owner from libel and dissemination of false or private information in social networks, and so forth.

Thirdly, the educational landscape of Ukraine is continuously changing. This issue is considered by the authors of the article "Structural-Functional Models of Integration and Reintegration of Ukrainian Educational Landscape" [15]. However, it is necessary that the changes should not be determined by the political situation, but by cultural traditions; they should not be determined by populism but should focus on economic growth and social protection of the population. This requires the models in the educational landscape to consider the Institution of the ownership right as an important basis of the economic and, respectively, national security strategy of Ukraine. Thus, as in the national security strategies of European States, the economic security is to be the key to the peaceful development of Ukraine.

Fourthly, the Ukrainian national idea as well as the image of the ideal Ukrainian policy should include not only national and cultural components, but also economic ones. In the modern realities, the economic power of the state is the defining characteristic of its geopolitical ambitions. The politician, whose legislative activities are focused on populism and not on the economic growth of the state, causes irreparable damage to the national security of the state.

Conclusions.

Thus, the authors have found three causes of instability of the Institution of property rights in Ukraine:

1. The Institution of the ownership right is formed and evolves exclusively within the boundaries of the legal science, while in the states of the European Union, property rights are seen primarily through the lens of economic theories.

2. Relatively short history of development of legal protection of property rights and the impact of postCommunist ideology. 
3. The lack of formation of traditions of respect for private property and the right to protection of property in the educational programs of secondary and higher educational establishments.

The defined reasons allowed the authors to propose a strategy of development of the Institution of ownership right, which will act as a vital component of the security strategy of Ukraine. The strategy of development of the Institution of right of ownership includes the following main provisions:

1. Legislation that provides legal protection of property rights in Ukraine, it should develop from economic and social theories.

2. The basics of legal protection of property rights should be included in educational curricula in secondary educational establishments, so that students know the constitutional norms which protect them from material and moral damage.

3. It is necessary that the models in the educational landscape regard the Institution of the right of ownership as one of the foundations of economic and, consequently, national security strategy of Ukraine.

4. The Ukrainian national idea should include not only a national-cultural component, but also an economic one.

\section{References.}

1. Bazaluk, O., 2016. Corruption in Ukraine: Rulers' Mentality and the Destiny of the Nation, Geophilosophy of Ukraine. Cambridge Scholars Publishing.

2. Rahmani, Z. and Tytarenko, V., 2018. Corruption in Afghanistan: an Experience for Ukraine. Ukrainian Policymaker, 2, pp. 27-32. DOI: 10.29202/up/2/4.

3. Hnativ, O., 2013. Protection of Owners' Rights under the Civil Law of Ukraine in Conditions of Wrongful Legal Acts that Violate Property Rights. Gentes et Nationes [online], 8, pp. 75-84. Available at: <http://gentes.wsa. bielsko.pl/> [Accessed 11 December 2017].

4. Haritonov, E. O. and Haritonova, O. I., 2015. Understanding the concept and content of private law as a subject of discussion. Scientific works of the National University “Odessa Law Academy”, 15, pp. 58-65.

5. Dzera, O. V., Kuznetsova, N. S. and Lyts, V. V., eds., 2013. The Science and Practical Commentary of the Civil Code of Ukraine, Volume 2. Kyiv: Yurinkom Inter.

6. Posner, R., 2014. Economic Analysis of Law. $9^{\text {th }}$ ed. Wolters Kluwer Law \& Business.

7. Fatkhutdinova, I., 2015. The Influence of the Ideological Apparatus of Coercion on the Ukrainian Women's Role in the Family and Marital Relations during the Social and Political Upheavals. Future Human Image, 2(5), pp. 101-124.

8. Cheremisin, O. and Herasymenko, M., 2018. The Dialectics of the Authority and Morality on the South of Ukraine at the End of $18^{\text {th }}$, the Early $20^{\text {th }}$ Centuries. Ukrainian Policymaker, 2, pp. 4-11. DOI: 10.29202/up/2/1.

9. Fatkhutdinov, V. and Bazaluk, O., 2018. The Importance of the Brain Neuro-Programming Technologies in National and Regional Security Strategies. Philosophy and Cosmology, 20, pp. 74-82. DOI: 10.29202/philcosm/20/6.
10. Ušiak, J. and Lasicová, J., 2016. Identities of central European states in terms of formation of security environment. Annual of Language and Politics and Politics of Identity, 10(1), pp. 45-59.

11. Bazaluk, O., 2017. Plato's and Isocrates' Traditions in the Development of Educational Theories in the History of Culture. Annals of the University of Craiova Philosophy Series, 40(2), pp. 5-18.

12. Bazaluk, O., 2018. The Feature Transformations of the Basic Meanings of Greek Paideia in the Educational Theories in the Middle Ages. Schole, 12.1, pp. 243-258. DOI: 10.21267/AQUILO.2018.12.10428.

13. Nelipa, D., Batrymenko, O., Rudenko, S. and Liashenko, I., 2018. Higher education management in Ukraine: Will generation change help us transform it faster? Naukovyi Visnyk Natsionalnoho Hirnychoho Universytetu, 3, pp. 167-175. DOI: 10.29202/nvngu/2018$3 / 19$.

14. Rudenko, S., Sapenko, R., Bazaluk, O. and Tytarenko, V., 2018. Management Features of International Educational Projects Between Universities of Poland and Ukraine. Naukovyi Visnyk Natsionalnoho Hirnychoho Universytetu, 2, pp. 142-147. DOI: 10.29202/nvn$\mathrm{gu} / 2018-2 / 21$.

15. Bazaluk, O., Svyrydenko, D. and Terepyshchyi, S., 2017. Structural-Functional Models of Integration and Reintegration of Ukrainian Educational Landscape. Naukovyi Visnyk Natsionalnoho Hirnychoho Universytetu, 5, pp. 163-168.

\section{Особливості правового захисту права власності в Україні та країнах Европейського Союзу}

\section{В. В. Заросило ${ }^{1}$, Ю. Г. Коросташивець ${ }^{1}$, Л. О. Максимова ${ }^{2}$, С. В. Нечипорук ${ }^{3}$}

1 - Київський державний коледж туризму та готельного господарства, м. Київ, Україна, e-mail: juliakutep@gmail. com

2 - Київський університет туризму, економіки та права, м. Київ, Україна, e-mail: laramaximova@gmail.com

3 - Національна школа суддів України, м. Київ, Україна, e-mail: mfkoorg@gmail.com

Мета. Розробити стратегію розвитку інституту права власності, що виступить важливою складовою частиною національної стратегії безпеки. Розглянути законотворчі способи підвищення інвестиційної привабливості та економічного потенціалу українських підприємств, рівень соціальної захищеності населення. На основі досвіду захисту прав власності в державах Європейського Союзу довести, що основу правового захисту права власності повинна складати економічна доцільність, а не політична кон'юнктура виконавчої й законодавчої влади.

Методика. Автори використовували метод порівняльно-правового аналізу, що дозволив порівняти особливості правового захисту права власності в Україні та державах Европейського Союзу й прийти до певних висновків. Історико-правовий 
метод дозволив авторам встановити закономірності й тенденції розвитку захисту права власності в цілому і в окремих елементах. Логіко-юридичний метод наукового пізнання дозволив авторам сформулювати висновки, необхідні для закріплення соціальної значущості інституту права власності в Україні.

Результати. Автори виявили три причини нестабільності інституту права власності в Україні:

1. Інститут права власності сформувався й розвивається виключно в межах юридичної науки, тоді як у державах Європейського Союзу права власності розглядаються, перш за все, через призму економічних теорій.

2. Відносно коротка історія розвитку правового захисту права власності та вплив посткомуністичної ідеології.

3. Відсутність в освітніх програмах середніх і вищих навчальних закладів традицій формування шанобливого ставлення до приватної власності та права захисту власності.

Встановлені причини не тільки не сприяють розвитку інституту права власності й можливостей iii правового захисту, але й підривають основи економічної та національної безпеки України.

Наукова новизна. Автори встановили, що правовий захист права власності є важливою характеристикою економічної безпеки України. Автори запропонували стратегію розвитку інституту права власності, що має важливий вплив на стратегію безпеки України. Стратегія розвитку інституту права власності включає наступні основні положення: законотворчість, що забезпечує правовий захист права власності в Україні, має базуватися на економічних і соціальних теорій; основи правового захисту права власності необхідно включити до освітніх програм середніх навчальних закладів, щоб учні знали конституційні норми, які захищають їх від майнової й моральної шкоди; необхідно, щоб у моделях освітнього ландшафту інститут права власності розглядався як одна з основ економічної й, відповідно, національної стратегії безпеки України; українська національна ідея повинна включати в себе не тільки національно-культурну складову, але й економічну. У сучасних реаліях економічна міць держави $€$ визначальною характеристикою його геополітичних амбіцій.

Практична значимість. Отримані у ході дослідження результати можуть використовуватися: а) у науково-дослідній сфері, з проблем захисту права власності; б) у сфері правотворчості, для удосконалення законодавчих і підзаконних актів, що регулюють права власності в Україні; в) у судовій практиці, для однакового застосування положень цивільного права при розгляді судами загальної юрисдикції та господарськими судами спорів, пов'язаних із правовим захистом права власності.

Ключові слова: інститут права власності, економічна безпека, економічний аналіз права, економічна теорія права власності

\section{Особенности правовой защиты права собственности в Украине и государствах Европейского Союза}

\author{
В. В. Заросило ${ }^{1}$ Ю. Г. Коросташивеи ${ }^{1}$, \\ Л. А. Максимова ${ }^{2}$, С. В.Нечипорук ${ }^{3}$
}

1 - Киевский государственный колледж туризма и гостиничного хозяйства, г. Киев, Украина, e-mail: juliakutep@ gmail.com

2 - Киевский университет туризма, экономики и права, г. Киев, Украина, e-mail: laramaximova@gmail.com

3 - Национальная школа судей Украины, г. Киев, Украина, e-mail: mfkoorg@gmail.com

Цель. Разработать стратегию развития института права собственности, которая выступит важной составной частью национальной стратегии безопасности. Рассмотреть законотворческие способы повышения инвестиционной привлекательности и экономического потенциала украинских предприятий, уровень социальной защищенности населения. На основе опыта защиты прав собственности в государствах Европейского Союза доказать, что основу правовой защиты права собственности должна составлять экономическая целесообразность, а не политическая конъюнктура исполнительной и законодательной власти.

Методика. Авторы использовали метод сравнительно-правового анализа, который позволил сравнить особенности правовой защиты права собственности в Украине и государствах Европейского Союза и прийти к определенным выводам. Историко-правовой метод позволил авторам установить закономерности и тенденции развития защиты права собственности в целом и в отдельных элементах. Логико-юридический метод научного познания позволил авторам сформулировать выводы, необходимые для закрепления социальной значимости института права собственности в Украине.

Результаты. Авторы обнаружили три причины нестабильности института права собственности в Украине:

1. Институт права собственности сформировался и развивается исключительно в границах юридической науки, тогда как в государствах Европейского Союза права собственности рассматриваются, прежде всего, через призму экономических теорий.

2. Относительно короткая история развития правовой защиты права собственности и влияние посткоммунистической идеологии.

3. Отсутствие в образовательных программах средних и высших учебных заведений традиций формирования уважительного отношения к частной собственности и праву защиты собственности.

Установленные причины не только не способствуют развитию института права собственности и возможностей её правовой защиты, но и подрывают основы экономической и национальной безопасности Украины.

Научная новизна. Авторы установили, что правовая защита права собственности является важ- 
ной характеристикой экономической безопасности Украины. Авторы предложили стратегию развития института права собственности, которая оказывает важное влияние на стратегию безопасности Украины. Стратегия развития института права собственности включает следующие основные положения: законотворчество, обеспечивающее правовую защиту права собственности в Украине, должно исходить из экономических и социальных теорий; основы правовой защиты права собственности необходимо включить в образовательные программы средних учебных заведений, чтобы ученики знали конституционные нормы, которые защищают их от имущественного и морального вреда; необходимо, чтобы в моделях образовательного ландшафта институт права собственности рассматривался как одна из основ экономической и, соответственно, национальной стратегии безопасности Украины; украинская национальная идея должна включать в себя не только национально-культурную составляющую, но и экономическую. В современных реалиях экономическая мощь государства является определяющей характеристикой его геополитических амбиций.

Практическая значимость. Полученные в ходе исследования результаты могут использоваться: а) в научно-исследовательской сфере, по проблемам защиты права собственности; б) в сфере правотворчества, для усовершенствования законодательных и подзаконных актов, регулирующих права собственности в Украине; в) в судебной практике, для единообразного применения положений гражданского права при рассмотрении судами общей юрисдикции и хозяйственными судами споров, связанных с правовой защитой права собственности.

Ключевые слова: институт права собственности, экономическая безопасность, экономический анализ права, экономическая теория права собственности

Рекомендовано до публікації докт. юрид. наук О.П.Васильченком. Дата надходження рукопису 09.11.17. 